Annual Research \& Review in Biology

12(3): 1-14, 2017; Article no.ARRB.32450

ISSN: 2347-565X, NLM ID: 101632869

SCIENCEDOMAIN international

www.sciencedomain.org

\title{
Antimicrobial Activities of Some Marine Sponges, and Its Biological, Repellent Effects against Culex pipiens (Diptera: Culicidae)
}

\author{
Ahmed I. Hasaballah ${ }^{1^{*}}$ and Hussein A. El-Naggar ${ }^{1}$ \\ ${ }^{1}$ Department of Zoology, Faculty of Science, Al-Azhar University, Cairo, Egypt.
}

Authors' contributions

This work was carried out in collaboration between both authors. Both authors read and approved the final manuscript.

Article Information

DOI: $10.9734 / A R R B / 2017 / 32450$

Editor(s):

(1) Tony Gutierrez, School of Life Sciences, Heriot-Watt University, UK. (2) George Perry, Dean and Professor of Biology, University of Texas at San Antonio, USA.

Reviewers:

(1) Akobi Oliver Adeyemi, Federal Medical Centre, Nigeria. (2) Eliton da Silva Vasconcelos, Federal University of São Carlos - UFSCar, Brazil.

(3) G. Annadurai, Manonmaniam Sundaranar University, Tamil Nadu, India. Complete Peer review History: http://www.sciencedomain.org/review-history/18634

Original Research Article

Received $26^{\text {th }}$ February 2017 Accepted $10^{\text {th }}$ April 2017 Published $14^{\text {th }}$ April 2017

\section{ABSTRACT}

Crude extracts of marine sponges, Negombata magnifica and Callyspongia siphonella were tested for their antimicrobial activity besides larvicidal, pupicidal, adulticidal and other biological effects against the filarial vector Culex pipiens. Three sub-lethal concentrations ranging as $8.4,28.4$ and 47.6 ppm for N. magnifica and 44.5, 327.4 and $610.3 \mathrm{ppm}$ for $C$. siphonella were used.

The two marine sponges used in this study were collected from reefs by SCUBA diving. Spicules were prepared by dissolving the soft tissue of small pieces of sponge in sodium hypochlorite and washed with distilled water and ethanol. The extracts were tested for their antimicrobial activity; in addition, the biological activities of the three sub-lethal concentrations used were evaluated against laboratory reared $\mathrm{Cx}$. pipiens mosquito.

The results obtained showed interesting antifungal activity against fungal strains tested. $N$. magnifica extract showed quite promising broad-spectrum antibacterial activity due to its capacity to inhibit the growth of almost bacterial strains tested. Based on $\mathrm{LC}_{50}$ values, the toxicity of $N$. magnifica extract (47.6 ppm) was higher than that of $C$. siphonella (610.3 ppm). Mean larval and 
pupal durations of mosquitoes treated with $N$. magnifica extract were significantly $(P<0.05)$ prolonged at higher sub-lethal concentrations; meanwhile, C. siphonella showed non-significant $(\mathrm{P}>0.05)$ prolongation. The $N$. magnifica extract was found to be more effective against the adult emergence than $C$. siphonella. There was a pronounced effect of the tested extracts on the number of eggs laid per female and this effect was concentration dependent, the fecundity of mosquitoes treated with $N$. magnifica extract was significantly $(P<0.05)$ decreased to $86.7 \pm 5.8$ eggs/o, compared to $150 \pm 8.7 \mathrm{eggs} / q$ for the control group, while it was $116.7 \pm 5.8 \mathrm{eggs} / q$ for $C$. siphonella extract, vs. the control group. Vitellogenin synthesis and ovarian development of Cx. pipiens females were highly affected by tested extracts. Six protein bands with high molecular weights (175-90 KDa), which believed to be vitellogenin, were detected in the control group, while this number reduced to two bands in ovaries of $N$. magnifica and $C$. siphonella-treated females. Also, N. magnifica extract induced concentration dependent repellent activity against tested females mosquitoes than $C$. siphonella extract. These promising results in relation with antifungal and antibacterial activities open the way for complementary investigation in order to purify and identify active molecules.

The present investigations have helped to focus on some bioactive substances isolated from marine resources; these molecules, which possess antimicrobial and insecticidal activities, could be used as insecticidal agents.

Keywords: N. magnifica; C. siphonella; antifungal; antibacterial; mosquitoes; reproduction; repellency.

\section{INTRODUCTION}

Mosquitoes top all the insect-vectors in transmission of serious diseases worldwide. Anopheles stephensi, Aedes aegypti and Cx. pipiens are the mosquitoes vector of malaria, dengue and lymphatic filariasis, respectively. Over two billion people in tropical countries are at risk from mosquito borne diseases and the search for effective vaccines against these diseases is still in progress [1]. The unplanned use of chemical insecticides during the past few decades to control insect pests have resulted in serious consequences such as insect resistance, mammalian toxicity, bioaccumulation through food chains, environmental contamination and risk for human health [2]. This necessitates the search for new sources for insect control agents.

A variety of antimicrobial substances have been isolated from various species of marine sponges [3]. Up to 800 antibiotic compounds have been isolated from marine sponges, a number that corroborates assumptions that sponges appear to defend themselves against infections by producing and/or accumulating secondary metabolites.

Marine sponges are among the richest sources of pharmacologically active chemicals from marine organisms. As infectious microorganisms evolve and develop resistance to existing pharmaceuticals, the marine sponge provides novel leads against bacterial, viral, fungal and parasitic diseases [4].

In the 1970s, natural product chemists embarked on exploitation of bioactive substances from marine invertebrates by using antimicrobial or cytotoxic assays. Later, several pharmaceutical companies joined this effort using more sophisticated assay systems, including enzyme inhibition assays. More than 15,000 marine products have been described $[5,6]$. So far, several promising candidates for new pharmaceuticals have been discovered from marine sponges [7]. Sponges and their associated microorganisms are responsible for more than 5,300 different products, and every year hundreds of new substances are discovered [8]. These early promises have now been substantiated by an overwhelming number of bioactive substances that have been discovered in marine organisms.

Secondary metabolites of marine organisms differ from that of terrestrial organisms. Bioactive compounds isolated from marine organisms exhibits various biological activities such as anti-cancer, anti-inflammatory, antifungal, antimicrobial and mosquito larvicidal properties $[9,10]$. The extracts of some marine sponges showed significant insecticidal activity against mosquito larvae and agricultural pests [11].

The aim of the current study was to evaluate the insecticidal properties of active molecules 
extracted from natural source (marine sponge), which could be later used as insecticidal agents.

\section{MATERIALS AND METHODS}

\subsection{Sponges Identification}

\subsubsection{Negombata (Latrunculia) magnifica (Keller, 1889)}

\subsubsection{Remarks}

Negombata magnifica or toxic finger-sponge, its reddish-brown narrow crooked branches can grow up to 70 centimeters in adult stage. It is extremely toxic because of latrunculin toxin. This sponge forming bright red to orange red branches, medium-sized slightly elevated oscules aligned with the branches. Size 30-70 $\mathrm{cm}$, and preferable occurred depth at 5-25 $\mathrm{m}$.

\subsubsection{Ecology}

This sponge lives on shallow coral reefs in the northern waters of the Red Sea and Indian Ocean. It is a potential source of the cytotoxin (latrunculin B), toxic to its predators.

\subsubsection{Callyspongia (Siphonochalina) siphonella (Levi, 1965)}

\subsubsection{Remarks}

Callyspongia siphonella is a sponge forming vertical erect tubes clusters from a common base. Its color is usually purple, pink or reddishbrown. It hasn't spicules, so these tubes have smooth consistency. The main skeleton consists of a set of primary horn fibers, exposed from the inside to the outer surface and a second set of fibers that lie at the right angles to the first one. It has a single mouth and adult can grow up to 50$60 \mathrm{~cm}$.

\subsubsection{Ecology}

C. siphonella a species of sponge endemic to the Red Sea, preferring to grow between corals and rocks, or under them it is often found on manmade constructions, from the shallow to deeper water. It feeds on plankton, inhabits reef slopes and has a temperature range of $22-28^{\circ} \mathrm{C}$ and preferable occurred depth at 2-35 $\mathrm{m}$.

\subsection{Mosquitoes Colony}

Mosquitoes used in this study were Culex pipiens L., they were collected from Abu-Rawash, Giza governorate, then were reared for several generations, in the insectary of medical entomology, zoology department, under controlled conditions of temperature of $27 \pm 2^{\circ} \mathrm{C}$, relative humidity $70 \pm 10 \%$ and $12-12$ light-dark regime. Adult mosquitoes were daily provided with cotton pieces soaked in $10 \%$ sucrose solution for a period of 3-4 days after emergence. After this period the females were allowed to take a blood meal from a pigeon host, which is necessary for laying eggs.

\subsection{Collection of Sponge Specimens}

Two marine sponges were used in this study, Negombata magnifica or toxic finger-sponge and Callyspongia siphonella or tube sponge, sponge sampling were done in shallow water at Blue Hole area, northern Red Sea, Egypt. Samples were collected from reefs by SCUBA diving during winter and spring 2016. The samples were cleaned and washed with distilled water and immediately frozen and stored at $-20^{\circ} \mathrm{C}$. Identification of all specimens has been carefully checked on the basis of morphological characters according to Systema Porifera [12] and the recent update undertaken in the World Porifera Database [13]. All specimens were fixed either for light microscopy in $4 \%$ formalin in seawater for $24 \mathrm{~h}$ and then preserved in ethanol $(70 \%)$. Spicules were prepared by dissolving the soft tissue of small pieces of sponge in sodium hypochlorite and washed five times with distilled water and two in ethanol. Cleaned spicules were dried on a slide and described for well identification.

\subsection{Preparation of the Crude Extracts}

The frozen sponges were cut into $\sim 1 \mathrm{~cm} 3$ cubes. The samples of sponge specimen were covered with $200 \mathrm{ml}$ methanol solvent. The macerated specimens were kept at room temperature for a week extraction period and genital shaken. Then, the residue was dried and extracted twice. Samples were filtered through Whatman 542 filter paper, and evaporated using rotary evaporator to obtain soluble extract [14]. Sublethal concentrations $\mathrm{LC}_{10}, \mathrm{LC}_{30}$ and $\mathrm{LC}_{50}$ were prepared as stock.

\subsection{Experimental Bioassay}

\section{$\underline{\text { 2.5.1 Antimicrobial effects }}$}

The extracts of, $N$. magnifica and $C$. siphonella were tested for their antifungal activity against 
Aspergillus fumigatus and Candida auris; antibacterial activity against different strains of bacteria namely; Staphylococcus haemolyticus, Bacillus subtilis, Staphylococcus epidermidis, Streptococcus sanguis, Streptococcus pyogenes, Streptococcus agalactiae, Enterococcus faecalis, Corynebacterium diphtheriae and (Methicillinresistant Staph. aureus; Staph. Epidermidis) as G+ve bacteria and Aeromonas veronii, Klebsiella pneumoniae, Campylobacter fetus, Proteus mirabilis, Acinetobacter baumannii, Serratia plymuthica, Salmonella typhi, Neisseria gonorrhoeae, Enterobacter cloacae and Shigella dysenteriae as $\mathrm{G}$-ve bacteria. These strains were obtained from Regional Center for Mycology and Biotechnology, Nasr City, Egypt. The occurrence of microbial growth inhibition was assessed using a classical diffusion method. In general, this method is based on the visual observation of microbial growth inhibition on agar media and determining the diameter of growth-inhibition zones in $\mathrm{mm}$. $50 \mu \mathrm{l}$ is the amount used to evaluate the microbial growth inhibition. All tests were done in triplicates and the listed data are the average of the obtained results.

In order to study the biological activity of these sponges, sub-lethal concentrations of each extract was used. The $2^{\text {nd }}$ instar larvae were collected from the established colony and placed in plastic cup containing $250 \mathrm{ml}$ of the extract solution as recommended by (WHO). Control larvae were placed in cups contained $250 \mathrm{ml}$ dechlorinated tap water (25 of $2^{\text {nd }}$ instar larvae/cup). At least three replicates were used in each experiment. The following biological aspects were tested:

\subsubsection{Larvicidal activity}

Larval mortality was recorded daily and dead larvae removed until adult emergence. Mortality of the larvae was indicated by a failure to respond to mechanical stimulation. Larval mortality percent (LM\%) was estimated by using the following equation: $L M \%=A-A=A \times 100$. Where: $A=$ number of tested larvae, $A=$ number of tested pupae [15].

\subsubsection{Pupation percent}

Pupation percent was estimated using the following equation: pupation $\%=a / \bar{a} \times 100$. Where: $a=$ number of observed pupae, $\bar{a}=$ number of tested larvae. The pupal mortality percentage (PM\%) was estimated by using the following equation: $\mathrm{PM} \%=n-\eta / n \times 100$. Where: $n=$ number of produced pupae, $\eta=$ number of observed adults. Pupal duration was calculated as the interval between the commencement of pupation and the commencement of adult emergence, it was calculated for each one and then the mean value was taken. The emerged adult males and females were counted and the adult emergence percent $(\mathrm{AE} \%)$ was calculated by using the following equation: $A E \%=E / E \times 100$. Where: $E=$ number of emerged adults, $\dot{E}=$ number of tested pupae [16].

\subsubsection{Female fecundity}

The adult females that succeeded to emerge from larvae treated with sub-lethal concentrations were collected and transferred with normal adult males obtained from the colony by using an electric aspirator recommended by (WHO), and fed with $10 \%$ sugar solution for three days. At day five, the starved females were allowed to take a blood meal from a pigeon and allowed to lay egg rafts on clean water. The number of eggs/raft was counted by using binocular microscope and the mean value was taken [16].

\subsubsection{Electrophoretic protein separation}

Forty $C x$. pipiens adult females resulted from $2^{\text {nd }}$ instar larvae treated with the $\mathrm{LC}_{50}$ of each extract were dissected under dissecting microscope 72 hr post blood meal (PBM), ovaries were excised, then put in $0.5 \mathrm{ml}$ sample buffer and kept deep frozen at $-20^{\circ} \mathrm{C}$ to separate the ovarian protein bands of females using sodium dodecyl sulfate polyacrylamide gel electrophoresis (SDS-PAGE).

Repellent activities: sub-lethal concentrations from each extract were dissolved in $2 \mathrm{ml}$ water with a drop of Tween 8. The concentration was directly applied onto ventral surface of pigeon after abdominal feathers removal. Ten min later, pigeons were placed for $2 \mathrm{hr}$ in cages containing starved $C x$. pipiens females. Control tests were carried out using ethanol or water. After treatments, the number of fed and unfed females were counted and calculated as described by [17], where Repellency $\%=(A \%-B \% / 100-$ $B \%) \times 100$. Where $A$ is the percentage of unfed females in treatment and $B$ the percentage of unfed females in control.

\subsection{Statistical Analysis}

The statistical analysis of the obtained data was done according to $[18,19]$ the analysis was revised and graphics were drawn by Excel for Microsoft office 2010. The obtained data were 
assessed by calculation of the mean (M), standard deviation (SD) and student t-test. $\mathrm{LC}_{50}$ was calculated using multiple linear regressions [20].

\section{RESULTS}

\subsection{Antimicrobial Activity}

The results are presented in (Table 1) and indicated by growth-inhibition zones, it was clear that $N$. magnifica extract had a much more potent antifungal activity than that of $C$. siphonella. Both G+ve and G-ve bacterial strains showed marked increase in the growth inhibition zones when treated with $N$. magnifica extract, except for $P$. mirabilis and Shigella dysenteriae. Meanwhile $C$. siphonella extracts showed slight to moderate antibacterial activity.

From the aforementioned results it is appeared that $N$. magnifica extract showed the highest antimicrobial activity against different fungal and bacterial strains tested, where it caused higher growth-inhibitory effects followed by $C$. siphonella extract.

\subsection{Biological Effects of Tested Extracts against $C x$. pipiens}

\subsubsection{Toxicity}

The mortality percentages of $C x$. pipiens larvae as influenced by different concentrations of $N$. magnifica are illustrated in (Fig. 1). The obtained data indicated that there was a positive correlation between the concentrations and the larval mortality percentages i.e. the increase of $N$. magnifica extract concentration led to increase of $\mathrm{LM} \%$. The LM\% increased gradually from $10.7 \%$ at the concentration of $10 \mathrm{ppm}$ to $94.7 \%$ at the concentration of $70 \mathrm{ppm}$. The LM\% among the control group was $1.3 \%$. The calculated $\mathrm{LC}_{50}, \mathrm{LC}_{30}$ and $\mathrm{LC}_{10}$ from the different mortality percentages using linear regression recorded 47.6, 28.4 and $8.4 \mathrm{ppm}$; respectively.

The larval mortality percentages of $C x$. pipiens larvae as influenced by different concentrations of C. siphonella are illustrated in (Fig. 2). The obtained data indicated that there was a positive correlation between the concentrations and the larval mortality percentages.

Table 1. Antimicrobial activity of $\boldsymbol{N}$. magnifica and $C$. siphonella

\begin{tabular}{llll}
\hline Tested microorganisms & N. magnifica & C. siphonella & Standard \\
\cline { 1 - 2 } Fungi & & $15.7 \pm 1.2$ & Amphotericin B \\
\hline Aspergillus fumigatus & $17.2 \pm 0.58$ & $23.7 \pm 1.2$ \\
Candida auris & $15.3 \pm 1.2$ & $13.7 \pm 1.5$ & $19.8 \pm 0.63$ \\
Gram positive bacteria & & & Ampicillin \\
Staphylococcus haemolyticus & $24.4 \pm 1.7$ & $20.2 \pm 0.58$ & $27.4 \pm 1.5$ \\
Bacillus subtilis & $30.3 \pm 0.58$ & $17.9 \pm 1.2$ & $32.4 \pm 2.1$ \\
Staphylococcus epidermidis & $21.3 \pm 0.63$ & $\mathrm{NA}$ & $23 \pm 1.0$ \\
Streptococcus sanguis & $19.7 \pm 1.5$ & $\mathrm{NA}$ & $21.7 \pm 1.5$ \\
Streptococcus pyogenes & $22.4 \pm 0.4$ & $20.2 \pm 1.5$ & $22.7 \pm 1.5$ \\
Streptococcus agalactiae & $14.3 \pm 0.62$ & $\mathrm{NA}$ & $22.3 \pm 1.5$ \\
Enterococcus faecalis & $16.3 \pm 1.2$ & $15.3 \pm 0.5$ & $19.3 \pm 0.58$ \\
Corynebacterium diphtheriae & $20 \pm 0.72$ & $\mathrm{NA}$ & $20 \pm 1.0$ \\
Methicillin -resistant microorganisms & & & Vancomycin \\
Staphylococcus aureus (MRSA & $19.9 \pm 1.2$ & $\mathrm{NA}$ & $21.6 \pm 2.1$ \\
Staphylococcus epidermidis (MRSE) & $22.1 \pm 0.58$ & $\mathrm{NA}$ & $22.4 \pm 1.5$ \\
Gram negative bacteria & & & Gentamicin \\
Aeromonas veronii & $22.1 \pm 0.3$ & $\mathrm{NA}$ & $23.7 \pm 1.3$ \\
Klebsiella pneumoniae & $21.4 \pm 0.62$ & $20.2 \pm 0.58$ & $20.2 \pm 1.2$ \\
Campylobacter fetus & $18.1 \pm 0.7$ & $\mathrm{NA}$ & $21.3 \pm 1.7$ \\
Proteus mirabilis & $\mathrm{NA}$ & $17.9 \pm 1.2$ & $21.2 \pm 1.2$ \\
Acinetobacter baumannii & $19.3 \pm 0.63$ & $23.3 \pm 0.63$ & $23.4 \pm 1.2$ \\
Serratia plymuthica & $18.3 \pm 1.2$ & $\mathrm{NA}$ & $22.3 \pm 0.58$ \\
Salmonella typhi & $15.6 \pm 0.6$ & $\mathrm{NA}$ & $21.1 \pm 0.72$ \\
Neisseria gonorrhoeae & $15.3 \pm 1.2$ & $\mathrm{NA}$ & $19.3 \pm 0.72$ \\
Enterobacter cloacae & $17.4 \pm 0.5$ & $21.8 \pm 0.58$ & $22.4 \pm 2.1$ \\
Shigella dysenteriae & $\mathrm{NA}$ & $13.3 \pm 1.2$ & $21.3 \pm 1.5$ \\
\hline & & & \\
\hline & & &
\end{tabular}




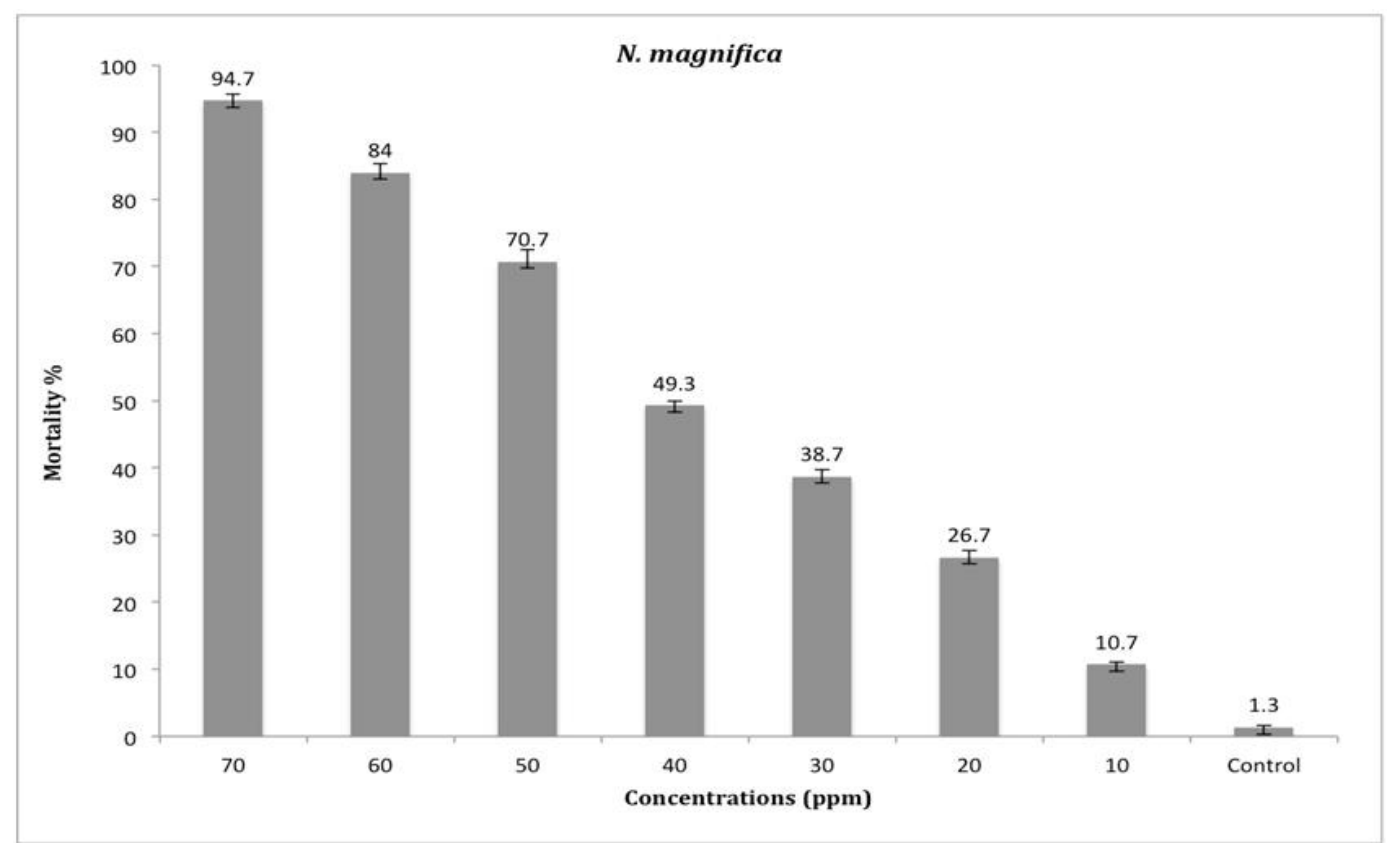

Fig. 1. Effect of different concentrations of $\boldsymbol{N}$. magnifica extract on larval mortality of Cx. pipiens

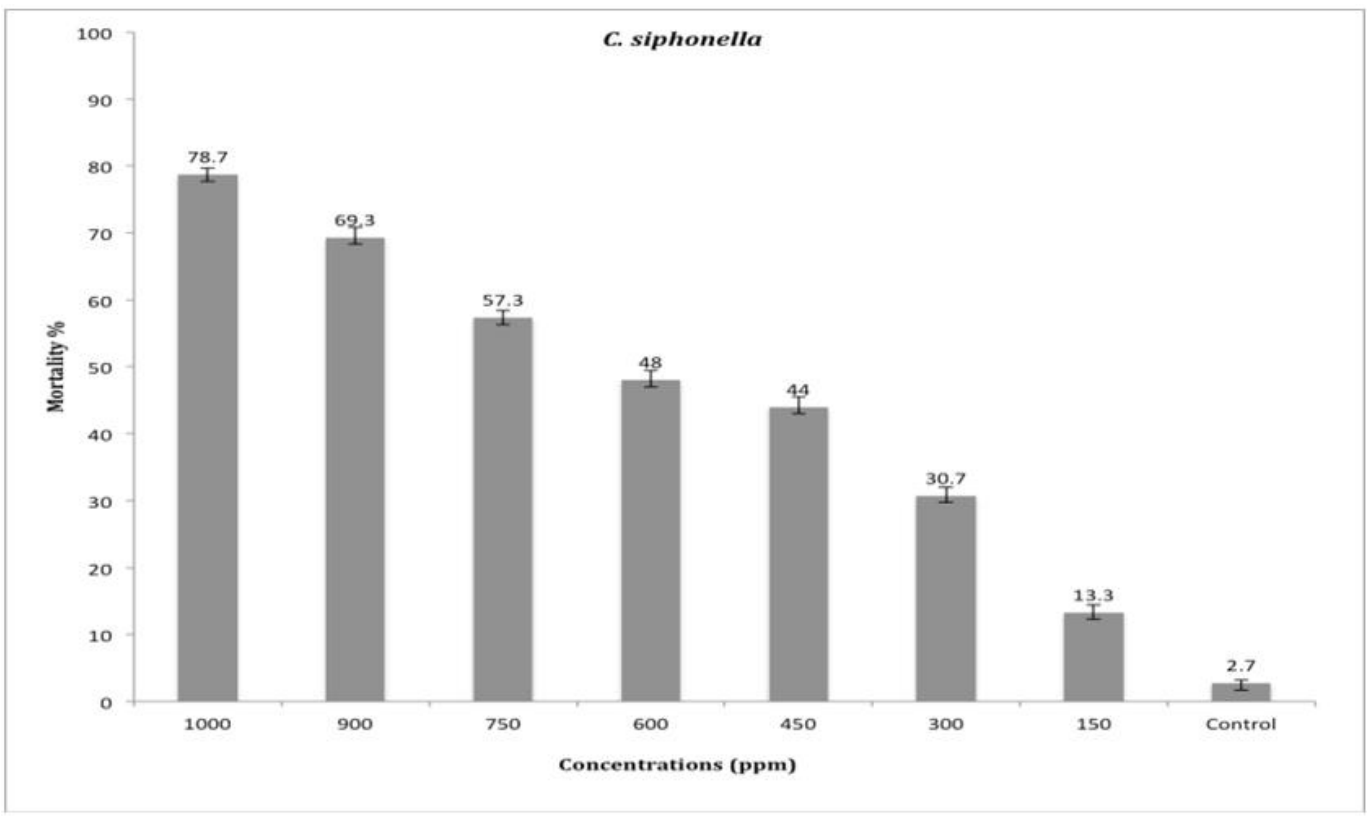

Fig. 2. Effect of different concentrations of $C$. siphonella extract on larval mortality of Cx. pipiens

The LM\% increased gradually from $13.3 \%$ at the concentration of $150 \mathrm{ppm}$ to $78.7 \%$ at the concentration of $1000 \mathrm{ppm}$. The LM\% among the control group was $2.7 \%$. The calculated $\mathrm{LC}_{50}$, $\mathrm{LC}_{30}$ and $\mathrm{LC}_{10}$ from the different mortality percentages using linear regression recorded
$610.3,327.4$ and 44.5 ppm; respectively. From the aforementioned results and based on $\mathrm{LC}_{50}$ values (Table 2), it is obvious that the toxicity of the $N$. magnifica extract was higher than that of C. siphonella. 
Table 2. Toxicity of sub-lethal concentrations of $\boldsymbol{N}$. magnifica and $\boldsymbol{C}$. siphonella against larvae of Cx. pipiens

\begin{tabular}{lllll}
\hline Extracts & \multicolumn{2}{c}{ Sub-lethal Conc. $(\mathrm{ppm})$} & Slope $(\mathbf{b})$ & Correlation coefficient $\left(\mathbf{R}^{2}\right)$ \\
\hline N. magnifica & $\mathrm{LC}_{50}(\mathrm{ppm})$ & 47.6 & 1.4238 & 0.99379 \\
& $\mathrm{LC}_{30}(\mathrm{ppm})$ & 28.4 & & \\
& $\mathrm{LC}_{10}(\mathrm{ppm})$ & 8.4 & & \\
C. siphonella & $\mathrm{LC}_{50}(\mathrm{ppm})$ & 610.3 & 0.0707 & 0.97902 \\
& $\mathrm{LC}_{30}(\mathrm{ppm})$ & 327.4 & & \\
& $\mathrm{LC}_{10}(\mathrm{ppm})$ & 44.5 & & \\
\hline
\end{tabular}

\subsubsection{Biological activity}

The biological activity of tested extracts against $C x$. pipiens has been studied. The larval duration, pupal duration, pupal mortality, adult emergence, female fecundity, ovarian proteins electrophoresis and repellency effects were assessed.

Data given in (Table 3) showed that, sub-lethal concentrations of $N$. magnifica extract have significantly $(P<0.05)$ prolonged the MLD to $12.3 \pm 0.3$ and $13.5 \pm 0.9$ days, at concentrations of 28.4 and $47.6 \mathrm{ppm}$; respectively, compared to $10.6 \pm 0.6$ days for the control group. Meanwhile, there was a non-significant $(P>0.05)$ prolongation of the MLD of the larvae treated with $C$. siphonella extract at sub-lethal concentrations used, vs. the control group.

The mean pupal duration was prolonged as the concentration used increased, the delayed effect was markedly observed in $N$. magnifica extract than the other one, the MPD significantly $(P<0.05)$ recorded $3.5 \pm 0.12$ and $3.8 \pm 0.15$ days for $\mathrm{LC}_{30}$ and $\mathrm{LC}_{50}$ of $\mathrm{N}$. magnifica extract; respectively, compared to $2.93 \pm 0.12$ days for the control group, and it was non-significantly $(P>0.05)$ recorded $2.96 \pm 0.05, \quad 3.2 \pm 0.2$ and $3.2 \pm 0.15$ days for the sub-lethal concentrations $\mathrm{LC}_{10}, \quad \mathrm{LC}_{30}$ and $\mathrm{LC}_{50}$ of $\mathrm{C}$. siphonella extract; respectively, compared to the untreated group.

A positive correlation between the concentrations and $\mathrm{PM} \%$ was observed. In the case of $N$. magnifica, the highest $\mathrm{PM} \%$ was $25 \%$ at concentration of $47.6 \mathrm{ppm}$ and the lowest PM\% was $4.5 \%$ at concentration of $8.4 \mathrm{ppm}$, vs. $0.0 \%$ in the control group. On the other hand, concentration of $610.3 \mathrm{ppm}$ gives the highest PM\% (15.4\%), while the lowest PM\% was (4.8\%) at concentration of $44.5 \mathrm{ppm}$, compared to the untreated group.

There was a marked reduction in the percentage of the adult emergence at sub-lethal concentrations used, as it recorded 84,68 and $36 \%$ for $\mathrm{LC}_{10}, \mathrm{LC}_{30}$ and $\mathrm{LC}_{50}$ of $\mathrm{N}$. magnifica extract; respectively, meanwhile it recorded 80 , 64 and $44 \%$ for $\mathrm{LC}_{10}, \mathrm{LC}_{30}$ and $\mathrm{LC}_{50}$ of $\mathrm{C}$. siphonella extract; respectively, vs. $100 \%$ for the control group.

Table 3. The effect of Sub-lethal concentrations of $\boldsymbol{N}$. magnifica and $\boldsymbol{C}$. siphonella against Cx. pipiens females

\begin{tabular}{|c|c|c|c|c|c|c|c|}
\hline Treatments & $\begin{array}{l}\text { Sub-lethal } \\
\text { Conc. (ppm) }\end{array}$ & $\begin{array}{l}\text { Tested } \\
\text { larvae }\end{array}$ & $\begin{array}{l}\text { MLD (days) } \\
\pm S D\end{array}$ & $\begin{array}{l}\text { MPD (days) } \\
\pm \text { SD }\end{array}$ & $\begin{array}{l}\text { Pupal } \\
\text { mortality } \\
\%\end{array}$ & $\begin{array}{l}\text { Adult } \\
\text { emergence } \\
\%\end{array}$ & $\begin{array}{l}\text { Fecundity } \\
\text { (Mean } \pm S D \text { ) }\end{array}$ \\
\hline \multirow[t]{3}{*}{ N. magnifica } & 47.6 & 25 & $13.5 c \pm 0.9$ & $3.8 c \pm 0.15$ & 25 & 36 & $86.7 d \pm 5.8$ \\
\hline & 28.4 & 25 & $12.3 b \pm 0.3$ & $3.5 b \pm 0.12$ & 5.6 & 68 & $111.7 c \pm 2.9$ \\
\hline & 8.4 & 25 & $10.3 a \pm 0.6$ & $3.1 \mathrm{a} \pm 0.2$ & 4.5 & 84 & $135 a \pm 5$ \\
\hline \multirow{3}{*}{ C. siphonella } & 610.3 & 25 & $11.3 a \pm 0.29$ & $3.2 a \pm 0.15$ & 15.4 & 44 & $113.3 b \pm 5.8$ \\
\hline & 327.4 & 25 & $11 a \pm 0.5$ & $3.2 \mathrm{a} \pm 0.2$ & 5.9 & 64 & $116.7 a \pm 11.54$ \\
\hline & 44.5 & 25 & $10.3 a \pm 0.6$ & $2.96 a \pm 0.05$ & 4.8 & 80 & $131.7 \mathrm{a} \pm 5.8$ \\
\hline Control & - & 25 & $10.6 a \pm 0.6$ & $2.93 a \pm 0.12$ & 0.0 & 100 & $150 \mathrm{a} \pm 8.7$ \\
\hline
\end{tabular}


Results also elucidated a pronounced effect of the tested extracts on the number of eggs laid this effect was concentration dependent. On the basis of $\mathrm{LC}_{50}$, the fecundity of $N$. magnifica extract was significantly $(P<0.05)$ decreased to $111.7 \pm 2.9$ and $86.7 \pm 5.8 \mathrm{eggs} /$ f for $\mathrm{LC}_{30}$ and $\mathrm{LC}_{50}$; respectively, compared to $150 \pm 8.7$ eggs/ 9 for the control group. On the other hand, the fecundity of females resulted from larvae treated with the sub-lethal concentrations of $C$. siphonella extract was nonsignificantly $(P>0.05)$ decreased except for the highest concentration tested $\left(\mathrm{LC}_{50}\right)$, where it recorded $116.7 \pm 11.54 \mathrm{eggs} /$, , vs. the control group.

\subsubsection{Electrophoretic protein separation}

The electrophoretically separated proteins of the ovaries homogenate of $C x$. pipiens females resulted from larvae treated with the $\mathrm{LC}_{50}$ of each extract tested and others of untreated females 72 $\mathrm{h}$, post blood meal (PBM) are shown in (Figs. 37). The obtained results displayed that the number of ovarian protein bands was 12 for the females resulted from larvae treated with the $\mathrm{LC}_{50}$ of $\mathrm{N}$. magnifica and $C$. siphonella, compared to 19 protein bands of the control group.

The results obtained illustrated three major protein bands with area percentages of 12.9 (M.W. $14 \mathrm{KDa}$ ), 14.7 (M.W. $39 \mathrm{KDa}$ ) and 22.5 (M.W. $170 \mathrm{KDa}$ ) among the ovarian protein bands of untreated females. Three major protein bands with area percentages of 16.5 (M.W. 30 KDa), 12.8 (M.W. $42 \mathrm{KDa}$ ) and 25.2 (M.W. 161 $\mathrm{KDa}$ ) were detected in $N$. magnifica-treated females. In addition, three major proteins among the ovarian protein bands of C. siphonella treated females, 20.6 (M.W. 14 KDa), 11.9 (M.W. $30 \mathrm{KDa}$ ) and 12.3 (M.W. $161 \mathrm{KDa}$ ) were detected.

Six protein bands with high molecular weights (175-90 KDa), which believed to be vitellogenin, with area percentages of 22.5 (170 KDa), 0.4 (134 KDa), 1.0 (115 KDa), 3.9 (101 KDa), 0.3 (95 $\mathrm{KDa})$ and 0.1 (90 KDa) were detected in the control group, while this number reduced to 2 protein bands, $\{25.2$ (161 KDa); 8.1 (115 KDa)\} and $\{12.3(161 \mathrm{KDa}) ; 9.8(115 \mathrm{KDa})\}$ in ovaries of N. magnifica and C. siphonella-treated females; respectively.

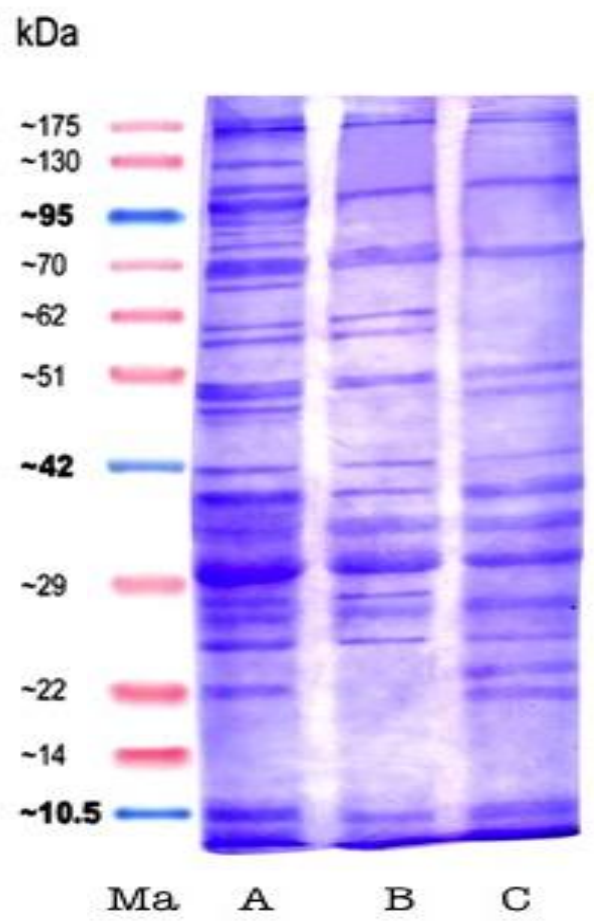

Fig. 3. Zymogram of ovaries homogenate of Cx. pipiens females treated with the $\mathrm{LC}_{50}$ of tested extracts and others of untreated females. (Ma) marker, (A) Control females, (B) N. magnifica treated females and (C) C. siphonella treated females 


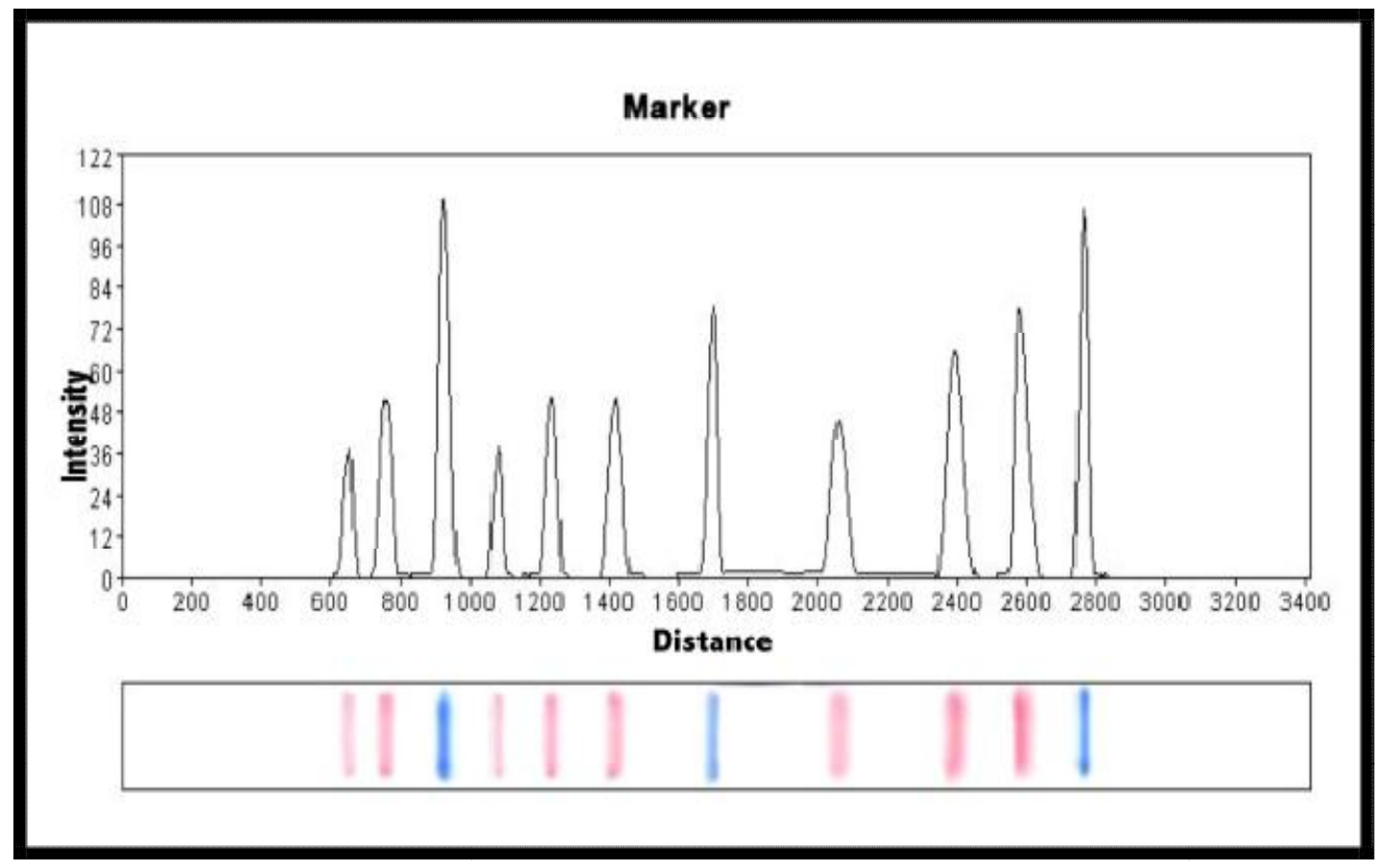

Fig. 4. Densitometric scan of protein electrophoretograms. (Marker)

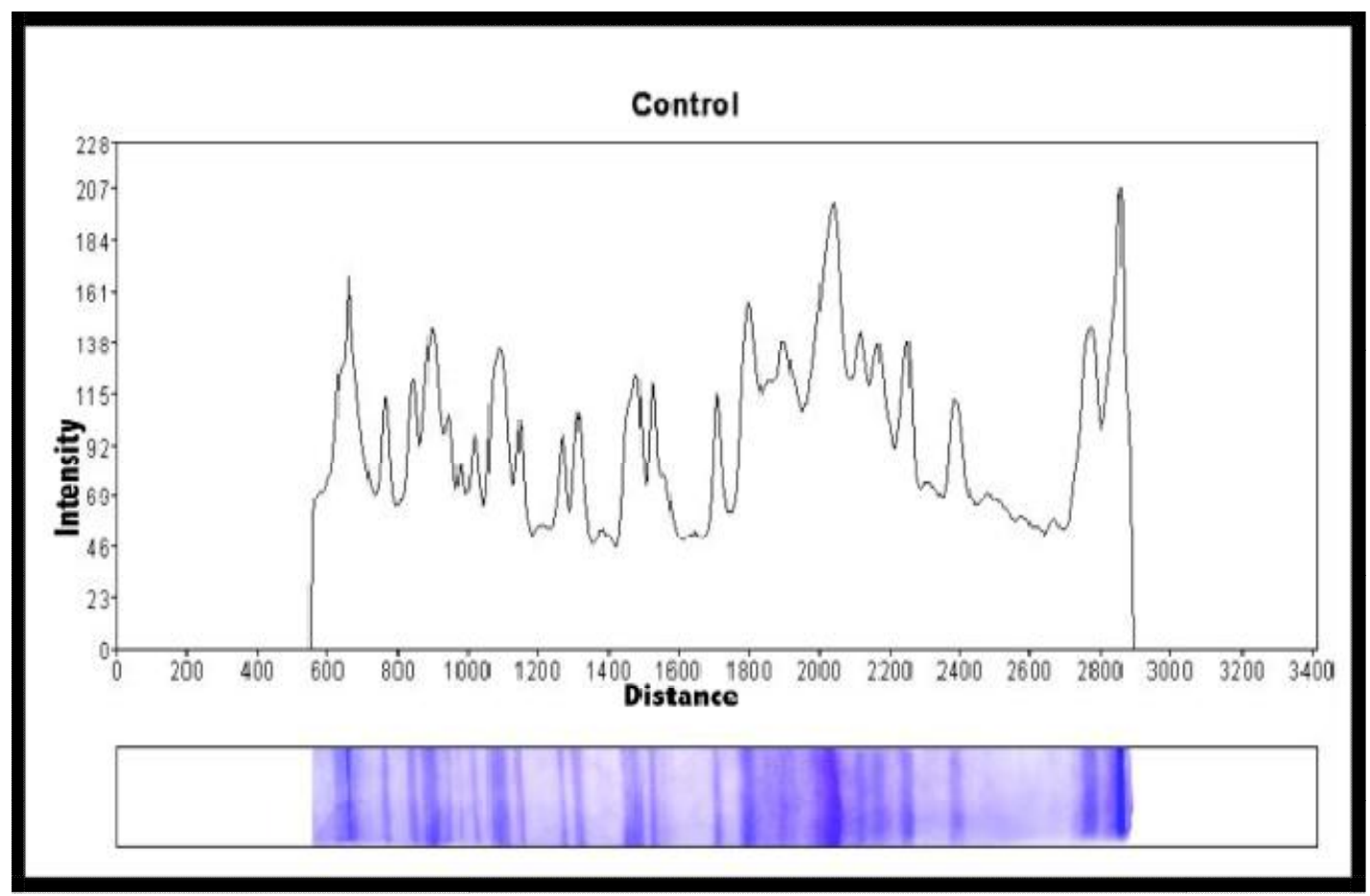

Fig. 5. Densitometric scan of protein electrophoretograms of $C x$. pipiens ovaries extracts, $72 \mathrm{~h}$ post blood meal. Control females 


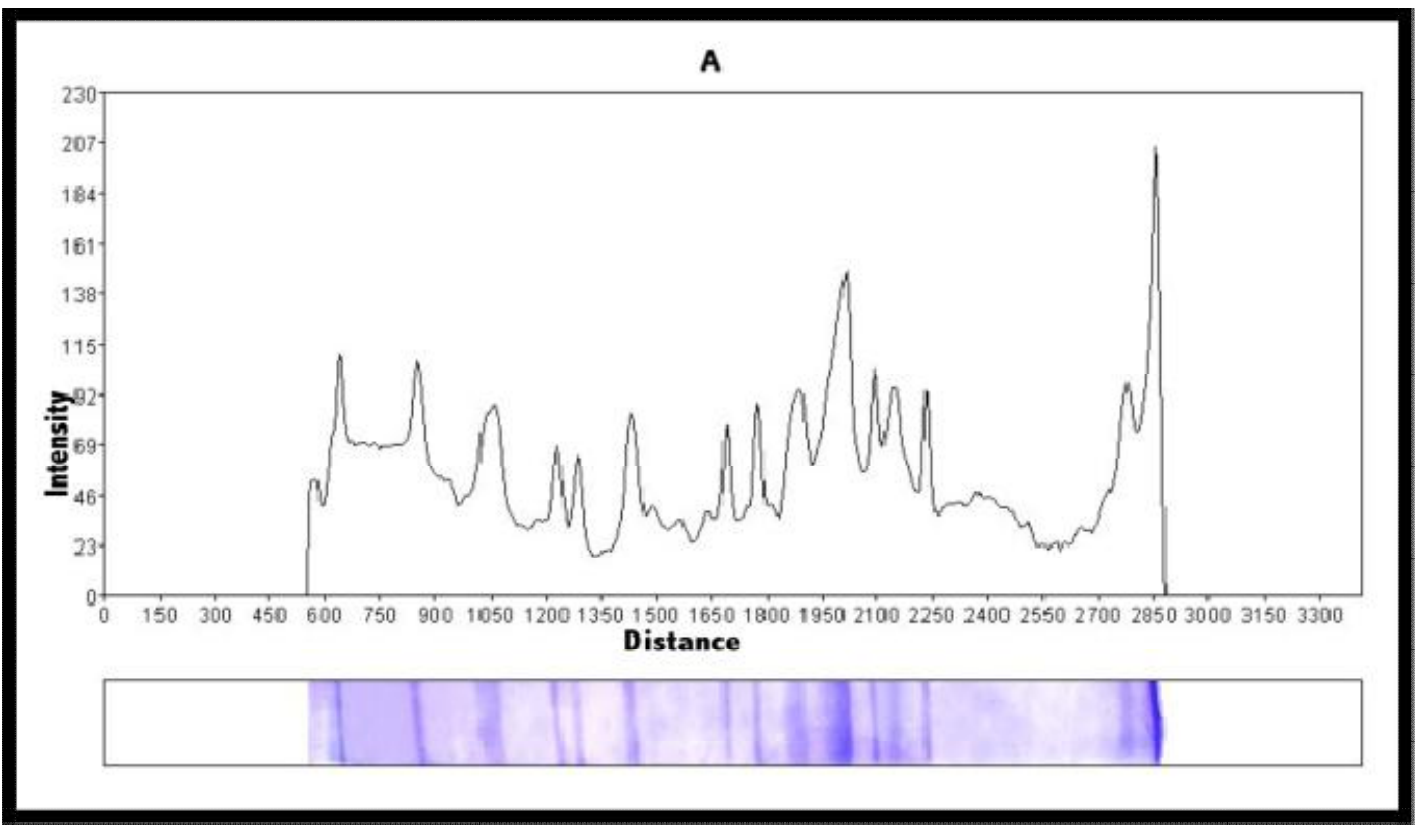

Fig. 6. Densitometric scan of protein electrophoretograms of $C x$. pipiens ovaries extracts, $72 \mathrm{~h}$ post blood meal. (A)- N. magnifica treated females

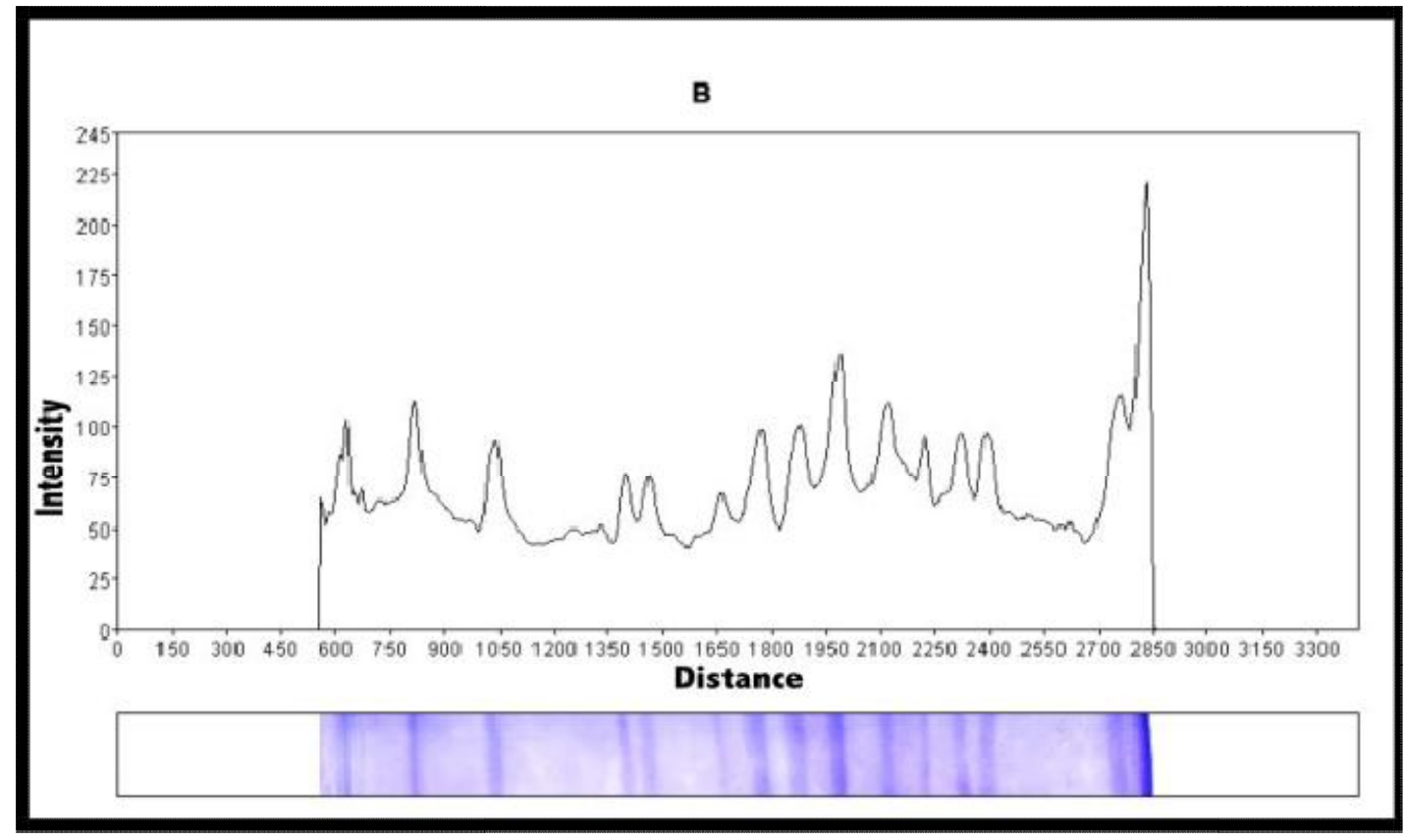

Fig. 7. Densitometric scan of protein electrophoretograms of $C x$. pipiens ovaries extracts, $72 \mathrm{~h}$ post blood meal. (B)- C. siphonella treated females

\subsection{Repellent Activities}

Data given in (Table 4) indicated that, $N$. magnifica extract had a much more repellent activity against $C x$. pipiens females than $C$. siphonella extract, and this activity was concentration dependent. The repellent activity of N. magnifica recorded $19.8,45.8$ and $73.8 \%$ for $\mathrm{LC}_{10}, \quad \mathrm{LC}_{30}$ and $\mathrm{LC}_{50}$; respectively, while it recorded $17.8,29.8$ and $65.8 \%$ for $\mathrm{LC}_{10}, \mathrm{LC}_{30}$ and $\mathrm{LC}_{50}$ of $C$. siphonella extract; respectively, vs. $0.0 \%$ of control females. 
Table 4. Repellency effect of $\boldsymbol{N}$. magnifica and $\boldsymbol{C}$. siphonella extracts against $\boldsymbol{C x}$. pipiens females

\begin{tabular}{|c|c|c|c|c|c|c|c|c|}
\hline \multirow{2}{*}{$\begin{array}{l}\text { Extracts } \\
N . \text { magnifica }\end{array}$} & \multicolumn{2}{|c|}{$\begin{array}{l}\text { Sub-lethal Conc. } \\
\text { (ppm) }\end{array}$} & \multirow{2}{*}{$\begin{array}{l}\begin{array}{l}\text { No. of } \\
\text { tested }+\end{array} \\
50\end{array}$} & \multirow{2}{*}{$\begin{array}{l}\begin{array}{l}\text { No. of } \\
\text { fed } q\end{array} \\
13\end{array}$} & \multirow{2}{*}{$\begin{array}{l}\% \text { of } \\
\text { fed } P \\
26\end{array}$} & \multirow{2}{*}{$\begin{array}{l}\begin{array}{l}\text { No. of } \\
\text { unfed } 9\end{array} \\
37\end{array}$} & \multirow{2}{*}{$\begin{array}{l}\begin{array}{l}\% \text { of } \\
\text { unfed }+9\end{array} \\
74\end{array}$} & \multirow{2}{*}{$\begin{array}{l}\begin{array}{l}\text { Repellency } \\
\%\end{array} \\
73.8\end{array}$} \\
\hline & $\mathrm{LC}_{50}(\mathrm{ppm})$ & 47.6 & & & & & & \\
\hline & $\mathrm{LC}_{30}(\mathrm{ppm})$ & 28.4 & 50 & 27 & 54 & 23 & 46 & 45.8 \\
\hline & $\mathrm{LC}_{10}(\mathrm{ppm})$ & 8.4 & 50 & 40 & 80 & 10 & 20 & 19.8 \\
\hline \multirow[t]{3}{*}{ C. siphonella } & $\mathrm{LC}_{50}(\mathrm{ppm})$ & 610.3 & 50 & 17 & 34 & 33 & 66 & 65.8 \\
\hline & $\mathrm{LC}_{30}(\mathrm{ppm})$ & 327.4 & 50 & 35 & 70 & 15 & 30 & 29.8 \\
\hline & $\mathrm{LC}_{10}(\mathrm{ppm})$ & 44.5 & 50 & 41 & 82 & 9 & 18 & 17.8 \\
\hline Control & -- & -- & 50 & 42 & 84 & 8 & 16 & 0.0 \\
\hline
\end{tabular}

\section{DISCUSSION}

The use of marine natural products is an alternative pest control method, which helps to minimize the usage of toxic pesticides and their deleterious effects on insects, livestock, wildlife and on the environment [21]. In recent years, researchers are concentrating on marine organisms to study their biological activities; especially, marine sponges (Porifera) which attracted significant attention from various scientific disciplines [22].

Negombata magnifica a conspicuous bright red branching sponge lives on shallow coral reefs in the northern waters of the Red Sea and Indian Ocean [23-26], it was never seen eaten by fish, when touched it releases a strong smelling reddish juice, this cytotoxic macrolides juice called latrunculins that found to be ichthyotoxic [27]. This toxin causes erratic behavior in fish followed by hemorrhaging, loss of balance and death. Another species used in this study was Callyspongia siphonella, this species one of the most widespread sponges in the northern Red Sea $[25,28,29]$. It is a rich source of triterpenoids [30] and this chemical product may hold promise for cancer treatment $[31,32]$.

Fungal infections remain a major direct cause of death in patients who are treated for a malignant disease, and emerging resistance is also an important problem $[33,34]$. Candida is most often associated with serious invasive fungal infections, but other Candida spp. and yeast-like organisms have emerged as etiological agents of severe mycoses. Tested extracts especially $N$. magnifica exhibited interesting antifungal activity against $A$. fumigatus and $C$. auris.

The discovery of the antibiotics in the first half of the 20th century left the society and the scientific community unprepared for the emergence of antibiotic-resistant bacteria. This resistance has rapidly spread, and the infections caused by Staph. aureus and other resistant strains of pathogenic bacteria are currently a considerable problem. Even vancomycin, which was the last resource for the treatment of infections by Methicillin-resistant Staph. aureus, recently has been rendered ineffective [35]. Clearly, the emergence and clinical significance of drug resistant bacterial infection has created an urgent need for the rapid and continued development of new classes of antibiotics.

The results obtained revealed interesting antibacterial activity against the different bacterial strains tested when treated with the extract of $N$. magnifica, where it caused remarkable growthinhibitory effects followed by the $C$. siphonella, these findings may be comparable with the previous findings [36], where they reported a high incidence of antibacterial activity against pathogenic bacteria treated with marine sponge crude extracts.

The results obtained showed also that, the used extracts exert some biological effects on the larva, pupa and adult stage of $C x$. pipiens. The survival potential of the larval stage was highly affected by extracts tested. The LM\% increased as the concentrations of extracts increased, $N$. magnifica was much more toxic against the larval stage followed by $C$. siphonella extract. These results may be in harmony with the previous findings [37], where they reported high toxicity of eleven marine sponges against larvae of $A e$. aegypti and Cx. quinquefasciatus $\left(\mathrm{LC}_{50}\right.$ at $<50$ ppm).

The obtained results revealed that, both tested extracts caused toxic effects on different stages of $C x$. pipiens mosquito, the MLD, MPD, pupal mortality \%, adult emergence and fecundity were significantly affected at higher concentrations, 
and this effect was concentration dependent. Concerning the effect of marine sponges on reproduction, reports on its toxic effects on insect reproduction are rare. The data obtained were in harmony with those obtained by [38], where the marine sponge Cliona celata methanol extract caused $100 \%$ ovicidal activity against $C x$. quinquefasciatus and $72 \%$ ovicidal activity against $A$. aegypti

In many insect species, proteins are selectively incorporated into the yolk of developing oocytes and eventually comprise $70-90 \%$ of the total yolk protein [39]. Because these proteins are essential for yolk formation and characteristic of only egg maturing females, they have been termed vitellogenins or female-specific proteins [40].

The effects of tested extracts on vitellogenin synthesis and ovarian development were tested by evaluating intensity and the number of protein bands in Cx. pipiens female's ovaries. Six protein bands with high molecular weights, which believed to be vitellogenin, were detected in the control group. While this number reduced to 2 protein bands in ovaries of $N$. magnifica and $C$. siphonella-treated females. The present results may be comparable to the previous findings of [41], where they found that three female-specific protein bands with high molecular weights were detected in the untreated vitellogenic Oncopeltus fasciatus females.

Remarkable repellent activity was also presented by tested extracts, where, $N$. magnifica showed a much more repellent activity against $C x$. pipiens females than $C$. siphonella extract and this activity was concentration dependent. These results maybe comparable with [38], where they tested the repellent activities of marine sponge Cliona celata extracts against $C x$. quinquefasciatus and Ae. aegypti.

\section{CONCLUSION}

The present investigations have helped to focus on some bioactive substances isolated from marine resources; these molecules, which possess antimicrobial and insecticidal activities, could be used as insecticidal agents.

\section{COMPETING INTERESTS}

Authors have declared that no competing interests exist.

\section{REFERENCES}

1. WHO. World Health Organization, Geneva; 2008.

Available:http://www.who.int/Inffs/en/fact09 4.html

2. Klein $W$. The future for insecticides. In: Metcalf RL, Mckelvey JJ (eds). Need and prospects. Wiley, New York; 1976.

3. Zaro BA. Marine sponges: A source of novel antibiotics. In Proceedings of the Western Pharmacological Society. 1981;25:11-13.

4. Laport MS, Santos OCS, Muricy G. Marine sponges: Potential sources of new antimicrobial drugs. Curr Pharm Biotechnol. 2009;10:86-105.

5. Lit M; 1999.

Available:http://www.chem.canterbury.ac.n z/marinlit/marinlit.html

6. Faulkner DJ. Marine natural products. Nat Prod Rep. 2000;17(1):7-55.

7. Kobayashi M. In search for biologically active substances from marine sponges, (Fusetani, N., Ed.), drugs from the Sea. Karger, Basel, Switzerland; 2000.

8. Faulkner DJ. Marine natural products. Nat Prod Rep. 2001;18(1):1R-49R.

9. Gul W, Hamann MT. Indole alkaloid marine natural products: An established source of cancer drug leads with considerable promise for the control of parasitic, neurological and other diseases. Life Sci. 2005;78:442-453.

10. Venkateswara-Rao J, Usman PK, BharatKumar J. Larvicidal and insecticidal properties of some marine sponges collected in Palk Bay and Gulf of Mannar. Afr J Biotechnol. 2008;7(2):109-113.

11. Baby J, Sujatha S, Jeevitha MV. Screening of pesticidal activities of some marine sponge extracts against chosen pests. J Biopesticides. 2010;3(2):495-498.

12. Hooper JNA, Van-Soest RWM. In Systema Porifera. A guide to the classification of sponges. New York, NY; 2002.

13. Van-Soest RWM, Boury-Esnault $\mathrm{N}$, Hooper JNA, Rützler K, de-Voogd NJ, Alvarez de-Glasby B, Hajdu E, Pisera AB, Vacelet J, Manconi R, Schoenberg C, Janussen D, Tabachnick KR, Klautau M, Picton B, Kelly M. World Porifera database; 2008.

Available:Http//www.marinespecies.org (Porifera). 
14. Ballantine DL, Gerwick WH, Velez SM, Alexander E, Guevara P. Antibiotic activity of lipid-soluble extracts from Caribbean marine algae. Hydrobiologia. 1987; 151/152:463-469.

15. Briggs JN. Reduction of adult house fly emergence by the effective Bacillus sp. on the development of immature forms. J Insect Pathol. 1960;2:418-432.

16. Hasaballah Al, Moselhy WA. Biological effects of some plant extracts against filariasis vector mosquito, Culex pipiens. Middle East J Appl Sci. 2015;5(4):10281034.

17. Abbott WS. A method for computing the effectiveness of an insecticide. J Eco Entomol. 1925;18:265-277.

18. Armitage P. Paired student ' $\mathrm{t}$ ' test. In 'Statistical methods in medical research' Black Well Scientific Pub Oxford London; 1974.

19. Lentner C, Lentner C, Wink A. Students tdistribution tables. In Geigy Scientific Tables. International Medical and Pharmaceutical Information, Ciba-Geigy Limited, Basal, Switzerland. 1982;2.

20. Finney DJ. Probit analysis third edition. Cambridge Univ Press; 1971.

21. Fatope MO, Ibrahim $\mathrm{H}$, Takeda $\mathrm{Y}$. Screening of higher plants reputed as pesticides using the brine shrimp lethality assay. Int J Pharmacogn. 1993;31:250254.

22. Thakur NL, Jain $R$, Natalio $F$, Hamer $B$, Thakur AN, Muller WEG. Marine molecular biology: An emerging field of biological sciences. Biotechnol Adv. 2008;26(3):233245.

23. Ilan M. Reproductive biology, taxonomy, and aspect of chemical ecology of Latrunculiidae (Porifera). Biol Bull. 1995;188:306-312.

24. Gillor O, Carmeli S, Rahamim Y, Fishelson $Z$, Ilan M. Immunolocalization of the toxin latrunculin B within the Red Sea sponge Negombata magnifica (Demospongiae, Latrunculiidae). Marine Biotechnol. 2000;2: 213-223.

25. Kelman D, Kashman Y, Rosenberg E, llan M, Ifrach I, Loya Y. Antimicrobial activity of the reef sponge Amphimedon viridis from the Red Sea. Aquat Microb Ecol. 2001;24: 9-16.

26. Rady $H$. Sponge Mesohyl induces antiproliferation activity and cell cycle arrest in colon cancer in-vitro. Research Journal of
Pharmaceutical, Biological and Chemical Sciences. 2014;5(6):1070-1075.

27. Neeman I, Fishelson L, Kashman Y. Isolation of a new toxin from the sponge Latrunculia magnifica in the Gulf of Aqaba (Red Sea). Mar Biol. 1975;30:293-296.

28. Gab-Alla AA, Kilada RW, Shalaby IM, Helmy T. Antimicrobial activity of some sponges from the Gulf of Aqaba. Egyptian J Biol. 2000;2:28-33.

29. Ilan M, Gugel J, Van-Soest RWM. Taxonomy, reproduction and ecology of new and known Red Sea sponges. Published in collaboration with the University of Bergen and the Institute of Marine Research Norway Sarsia. 2004;89: 388-410.

30. Simmons TL, McPhail KL, Ortega-Barría E, Mooberry SL, Gerwick WH, Belamide A. A new antimitotic tetrapeptide from a Panamanian marine cyanobacterium. Tetrahedron Lett. 2006;47:3387-3390.

31. Angawi R, Saqer E, Abdel-Lateff A, Badria FA, Ayyad SE. Cytotoxic neviotane triterpene-type from the Red Sea sponge Siphonochalina siphonella. Pharmacogn Mag. 2014;10:S334-41.

32. Al-Massarani SM, El-Gamal AA, Al-Said MS, AlLihaibi SS, Basoudan OA. In vitro cytotoxic, antibacterial and antiviral activities of triterpenes from the Red Sea sponge, Siphonochalina siphonella. Trop J Pharm Res. 2015;14(1):33-40.

33. Hazen KC. New and emerging yeast pathogens. Clin Microbiol Rev. 1995;8: 462-478.

34. Ellis $M$, Richardson $M$, de Pauw B. Symposium on invasive fungal infections: Epidemiology. Hosp Med. 2000;61:605609.

35. Rice LB. Antimicrobial resistance in grampositive bacteria. Am J Infect Control. 2006;34(5):S11-S19.

36. Becerro MA, Lopez NI, Turon X, Uriz MJ. Antimicrobial activity and surface bacterial film in marine sponges. J Exp Mar Biol Ecol. 1994;179:195-205.

37. Sujatha S, Joseph B. Effects of few marine sponges and it biological activity against Aedes aegypti Linn. and Culex quinquefasciatus. (Diptera: Culicidae). J Fish Aquat Sci. 2011;6(2):170-177.

38. Reegan AD, Kinsalin AV, Paulraj MG, Ignacimuthu S. Larvicidal, ovicidal, and repellent activities of marine sponge Cliona 
celata (Grant) extracts against Culex quinquefasciatus Say and Aedes aegypti L. (Diptera: Culicidae). ISRN Entomology. 2013;8. Article ID 315389

39. Highnam KC, Hill L. The comparative Endocrinology of the invertebrates, $2^{\text {nd }}$ edition. E Arnold, London; 1977.

40. Elliott $\mathrm{RH}$, Gillott C. An electrophoretic study of proteins of the ovary, fat body and haemolymph in the migratory grasshopper, Melanoplus sanguinipes. J Insect Physiol. 1979;25:405-410.

41. Cervera A, Maymó AC, Martinez-Pardo R, Garcera MD. Vitellogenesis inhibition in Oncopeltus fasciatus females (Heteroptera: Lygaeidae) exposed to cadmium. J Insect Physiol. 2005;51:895911.

(c) 2017 Hasaballah and El-Naggar; This is an Open Access article distributed under the terms of the Creative Commons Attribution License (http://creativecommons.org/licenses/by/4.0), which permits unrestricted use, distribution, and reproduction in any medium, provided the original work is properly cited.

Peer-review history:

The peer review history for this paper can be accessed here: http://sciencedomain.org/review-history/18634 